\title{
Endovascular aortic repair for aorto-esophageal fistula in a young man: have all loose ends been tied?
}

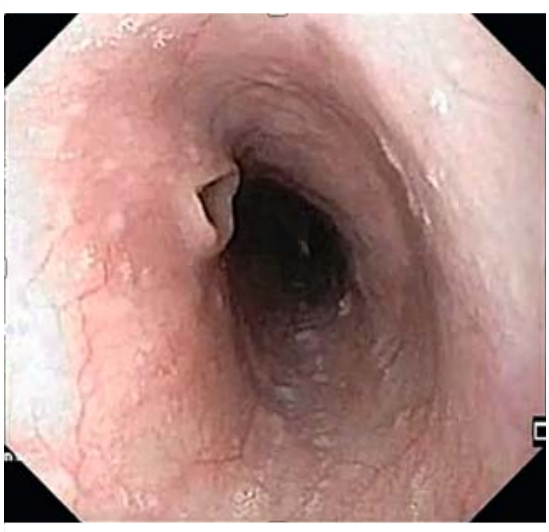

- Fig. 1 Endoscopy image revealing an ulcer at about $32 \mathrm{~cm}$ in the esophagus.

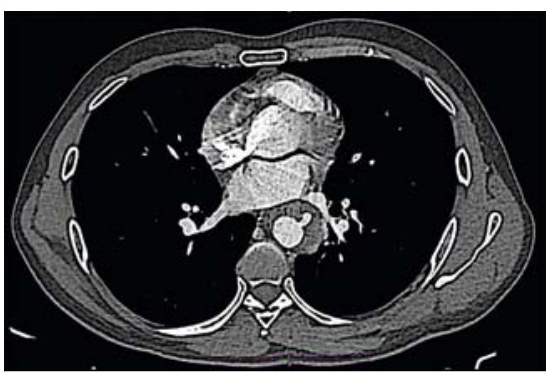

- Fig. 3 Computed tomography angiography shows a large hematoma around the thoracic aorta and contrast outpouching with expanding thrombus along the adjacent esophagus.

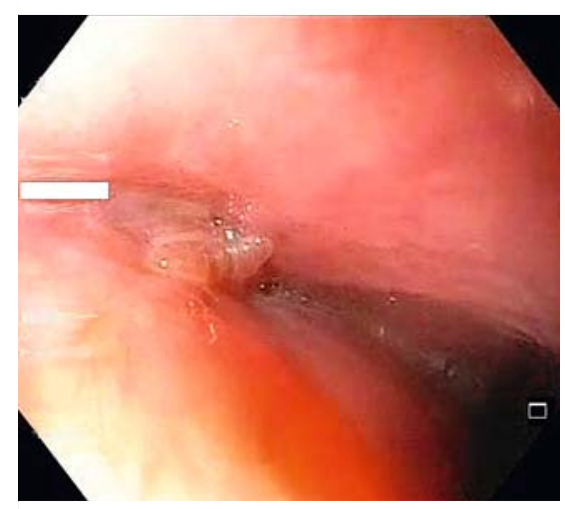

> Fig. 5 Near complete closure of the esophageal opening with granulation tissue at the site.

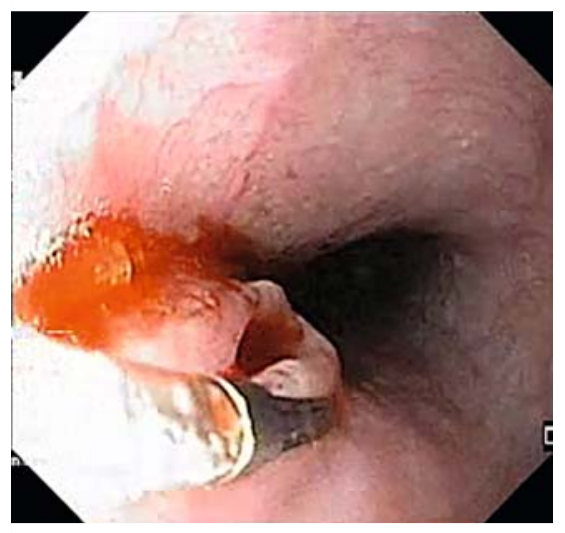

- Fig. 2 Endoscopic clip application at the site of esophageal ulcer.

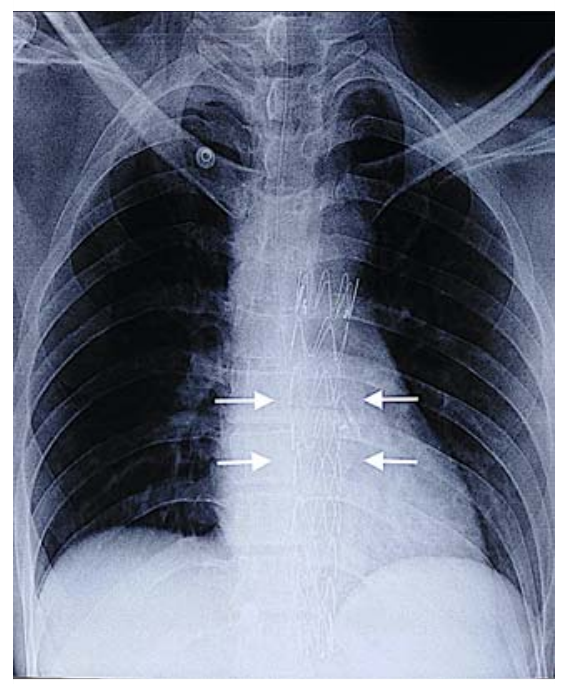

- Fig. 4 Chest X-ray revealing the position of the aortic stent graft.

A 36-year-old man presented with a history of large-volume hematemesis. Clinical examination revealed severe pallor, hypotension, and feeble peripheral pulses. After initial resuscitation, an upper gastrointestinal (GI) endoscopy was performed, which revealed an ulcerated lesion at about $32 \mathrm{~cm}$ from the incisors ( $\triangleright$ Fig.1). An attempt was made to close the ulcer with endoclips but was unsuccessful ( Fig.2). Contrast-enhanced computed tomography (CT) revealed a large hematoma around the thoracic aorta, contrast outpouching, and expanding thrombus along the adjacent esophagus, suggesting the diagnosis of an aorto-esophageal fistula ( Fig.3). The aortic rent was closed using an 8 to 10-mm patent ductus arteriosus closure device, and a nasogastric tube was placed for feeding.

He was apparently asymptomatic for 39 days, after which he had a repeat bout of hematemesis. Evaluation revealed displacement of the closure device. At this juncture, thoracic endovascular aortic repair was performed and an aortic stent graft (VAMF, 26-26-150; Medtronic, Minneapolis, Minnesota, USA) was placed ( $\triangleright$ Fig.4). On subsequent follow-up, endoscopy revealed a fistulous opening, and the aortic stent graft could be visualized through the opening (video image). The option of surgery and placing a covered esophageal stent was discussed with the patient. However, he was unwilling to undergo the procedure, and therefore nasojejunal feedings were continued for 2 months to prevent infection of the stent graft and allow for healing of the fistula. Subsequent endoscopy revealed healing of the fistulous opening with granulation tissue at the site of the previous fistulous opening ( $\triangleright$ Fig. 5 ).

An idiopathic aorto-esophageal fistula is a rare cause of upper GI bleeding, especially in young men with no prior history of aortic surgery [1]. Early diagnosis and management are crucial owing to the high mortality associated with this condition [2]. In this video case, we presented the course of a young man diagnosed with an aorto-esophageal fistula ( $\triangleright$ Video 1 ). In addition, we highlighted the importance of healing towards the esophageal site to prevent infection of the aortic stent graft.

Endoscopy_UCTN_Code_CCL_1AB_2AD_3AZ 


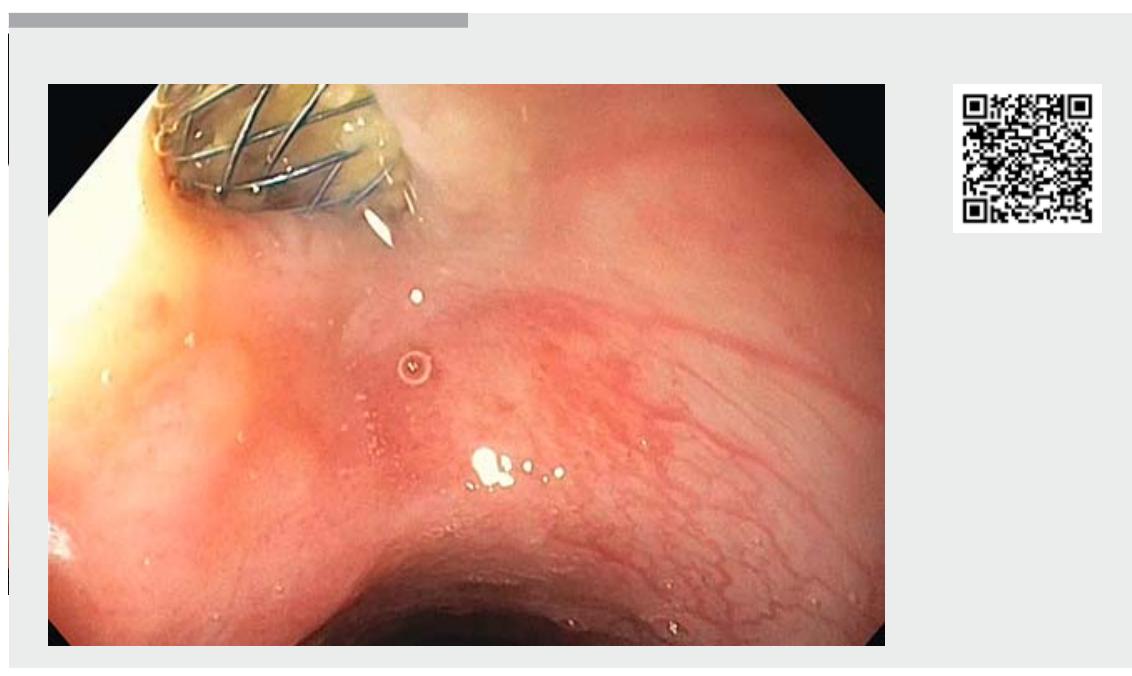

$\checkmark$ Video 1 Endovascular aortic repair of aorto-esophageal fistula with aortic stent graft after displacement of original closure device.

\section{Competing interests}

The authors declare that they have no conflict of interest.

The authors

\section{Sundeep Lakhtakia' ${ }^{1}$, Zaheer Nabi ${ }^{1}$, Sanjeev} Kumar $^{2}$, Srinivas Ila ${ }^{1}$, D. Nageshwar Reddy ${ }^{1}$

1 Asian Institute of Gastroenterology, Hyderabad, India

2 BIG Hospital, Agamkuan, Patna, India
Bibliography

Endoscopy 2021; 53: E336-E337

DOI 10.1055/a-1287-8799

ISSN 0013-726X

published online 3.11 .2020

(C) 2020. Thieme. All rights reserved.

Georg Thieme Verlag KG, Rüdigerstraße 14, 70469 Stuttgart, Germany

\section{ENDOSCOPY E-VIDEOS}

https:|/eref.thieme.de/e-videos

回解 Endoscopy E-Videos is a free F access online section, reporting 回舴: on interesting cases and new techniques in gastroenterological endoscopy. All papers include a high quality video and all contributions are freely accessible online.

This section has its own submission website at

https://mc.manuscriptcentral.com/e-videos
Asian Institute of Gastroenterology, 6-3-661, Somajiguda, Hyderabad - 500 082, India Fax: +91-40-2332-4255

zaheernabi1978@gmail.com

\section{References}

[1] Nabi Z, Asif S, Reddy DN. A rare cause of upper gastrointestinal bleed: bulge in lower esophagus is the clue. Gastroenterology 2020; 159: 50-52

[2] Deijen CL, Smulders YM, Coveliers HME et al. The importance of early diagnosis and treatment of patients with aortoenteric fistulas presenting with herald bleeds. Ann Vasc Surg 2016; 36: 28-34 